\title{
S GYNECOLOGICAL CANCER \\ Tertiary cytoreductive surgery by laparoscopy in granulosa cell tumor recurrence
}

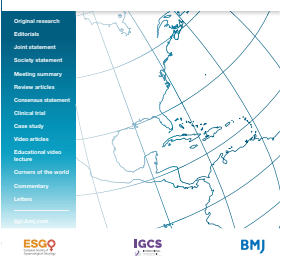

- Additional material is published online only. To view please visit the journal online (http://dx.doi.org/10.1136/ijgc2019-001079).

Gynecological Oncology Department, La Paz University Hospital, Madrid, Spain

Correspondence to Dr Virginia García Pineda, La Paz University Hospital Madrid 28046, Spain; virginia. garciapineda@gmail.com

Accepted 15 May 2020 Published Online First 1 July 2020

\begin{abstract}
Virginia García Pineda (D) , Alicia Hernández, María Cabanes (D) , Jaime Siegrist, Myriam Gracia Ignacio Zapardiel
\end{abstract}

Granulosa cell tumors are diagnosed in stage I in $95 \%$ of cases, with a rate of recurrence as high as $10-64 \%{ }^{1}$

The most common management of granulosa cell tumor recurrence is surgical treatment, achieving no visible residual disease because the presence of tumor after surgery seems to be associated with diminished progression-free survival and overall survival. ${ }^{2}$

During the last two decades, due to the advances in laparoscopic instrumentation and techniques, the use of minimally invasive surgery in the management of ovarian cancer patients has been actively explored for the assessment of interval surgical cytoreduction, for secondary cytoreductive surgery, and even for tertiary cytoreductive surgery in very selected patients.

Concerning primary debulking minimally invasive surgery, most studies report an overlap of oncological outcomes compared with traditional surgery. The selection of patients is crucial to a successful outcome using minimally invasive surgery.

Complete cytoreduction documented in the literature ranges from $78.9-98.3 \%$ of cases. In the study of Gallota et al, 58 patients with ovarian cancer recurrence underwent secondary cytoreductive surgery by laparoscopy, with complete cytoreduction in $100 \%$ of cases. Eriksson et al compared minimally invasive surgery with the laparotomic approach in secondary cytoreductive surgery, and found the rate of complete debulking was $95 \%$ and $93 \%$, respectively. For adequate selection of cases for laparoscopic cytoreduction, preoperative

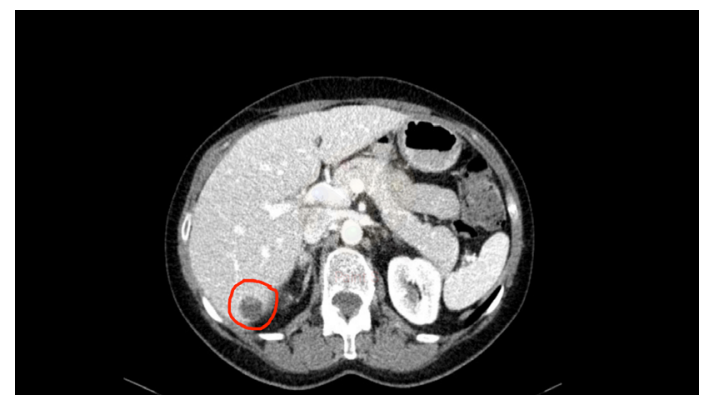

Figure 1 A cross-sectional image of a computed tomography scan showing the recurrence of a granulosa cell tumor at liver segment 6 .

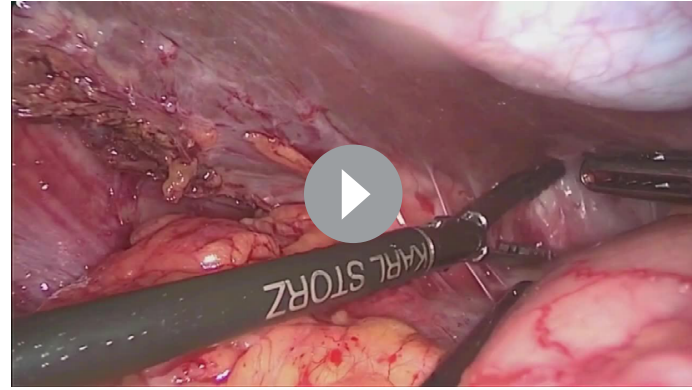

Video 1 Laparoscopic tertiary cytoreduction in

radiologic workup and intraoperative laparoscopic eval-

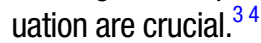

This video (Video 1) demonstrates that laparoscopic tertiary cytoreductive surgery in ovarian cancer is feasible in cases with visible and located tumor recurrence. For superior hemi-abdomen access we use a $10 \mathrm{~mm}$ umbilical trocar and three accessory $5 \mathrm{~mm}$ trocars at both flanks. A diagnostic laparoscopy should be done for surgical planning and to assess cytoreduction feasibility. In this case an endoscopic liver retractor could be useful in order to improve recurrence exposure which is at liver segment 6 (Figure 1). Ultrasonic devices and bipolar forceps allow careful and hemostatic dissection of tumorous tissue around the liver. Finally, marking the recurrence site with metallic hemoclips is useful for patient surveillance.

A laparoscopic approach in well selected patients is feasible and can achieve complete cytoreduction. It also enables early patient recovery and the timely start of adjuvant treatment.

Contributors All authors have participated in the development of this video article.

Funding The authors have not declared a specific grant for this research from any funding agency in the public, commercial or not-for-profit sectors.

Competing interests None declared.

Patient consent for publication Not required.

Provenance and peer review Not commissioned; externally peer reviewed.

Data availability statement All data relevant to the study are included in the article or uploaded as supplementary information. a granulosa cell tumor recurrence. 


\section{ORCID iDs}

Virginia García Pineda http://orcid.org/0000-0002-6434-3630

María Cabanes http://orcid.org/0000-0002-6213-7374

\section{REFERENCES}

1 Ray-Coquard I, Morice P, Lorusso D, et al. Non-epithelial ovarian cancer: ESMO clinical practice guidelines for diagnosis, treatment and follow- up. Ann Oncol 2018;29:iv1-18.
2 Karalok A, Ureyen I, Tasci T, et al. Maximum surgical effort is warranted for recurrent adult granulosa cell tumors of ovary. Tumori 2016;102:404-8.

3 Gallotta V, Conte C, Giudice MT, et al. Secondary laparoscopic cytoreduction in recurrent ovarian cancer: a large, single-institution experience. J Minim Invasive Gynecol 2018;25:644-50.

4 Eriksson AGZ, Graul A, Yu MC, et al. Minimal access surgery compared to laparotomy for secondary surgical cytoreduction in patients with recurrent ovarian carcinoma: perioperative and oncologic outcomes. Gynecol Oncol 2017;146:263-7. 